\title{
BOB DINGLE - PATHFINDER AT WAR AND IN THE ANTARCTIC
}

\author{
by Herbert J.G. Dartnall
}

(with one figure, eight plates and one appendix)

\begin{abstract}
Dartnall, H.J.G. 2018 (14:xii): Bob Dingle - pathfinder at war and in the Antarctic. Papers and Proceedings of the Royal Society of Tasmania 152: 53-59. https://doi.org/10.26749/rstpp.152.53 ISSN 0080-4703. Department of Biological Sciences, Macquarie University, NSW 2109, Australia. Email: herbdartnall@pip.com.au
\end{abstract}

\begin{abstract}
Bob Dingle (1920-2016) retired in 1975 to Swansea, Tasmania, after an adventurous and peripatetic working life. During the Second World War he served with Bomber Command. He was a wireless operator with 78 and 35 Squadrons, was decorated with the Distinguished Flying Medal and was commissioned. After the war he migrated to Australia and in 1950 joined the Commonwealth Bureau of Meteorology as a trainee weather observer with the express intention of serving in the Antarctic. Over the next 25 years he wintered seven times with the Australian and United States Antarctic programs, was awarded the Queen's Polar Medal with two clasps and served as the senior Australian weather observer for four years on the US Navy Ship Eltanin.
\end{abstract}

Key Words: Second World War, RAF pathfinder squadron, Antarctica, Heard Island, Davis, Wilkes, Plateau Station, Polar Medal.

\section{INTRODUCTION}

When Bob Dingle retired he moved to Swansea on the east coast of Tasmania where he quickly settled in as a generous and active member of this small town. It was pointless telephoning him during the day as he'd be pottering in his garden or out and about in the community. Mister Dingle, as he was universally known, helped deliver meals-on-wheels and library books to those confined to home, ferried local residents to Hobart for hospital appointments, visited the sick to see what he could do and for many years audited the local Anglican church accounts. His was a quiet, albeit active, retirement in stark contrast to his extremely varied, adventurous, exciting and peripatetic working life.

Born William Robert John Dingle on 5 November 1920 at home in Stithians, Cornwall, United Kingdom, Bob was the only surviving child of William Dingle and Miriam Jane Dingle, née Reed. There was a younger brother but he only lived for a few hours. Bob's father worked as a quarryman, where the rope and lashing skills he learnt whilst serving in the Royal Navy were in great demand. Bob was educated locally at the Helston Grammar School and on completion of his education in 1936 he secured a position with the General Post Office (GPO) as a sorting clerk and telephonist.

\section{WAR SERVICE}

With the advent of the Second World War Bob Dingle enlisted as an Aircraftsman second class in the Royal Air Force Volunteer Reserve on 10 October 1940. The following year he remustered as a Wireless Operator Air Gunner undergoing training at No 2 Signals School from 1 August 1941 and No 8 Air Gunnery School on 16 July 1942 (pl. 1). On 31 August 1942 Temporary Sergeant W.R.J. Dingle was posted to No 11 Operational Training Unit where he linked up with three New Zealanders who together formed the nucleus of a bomber crew. On 19 February 1943 they were posted

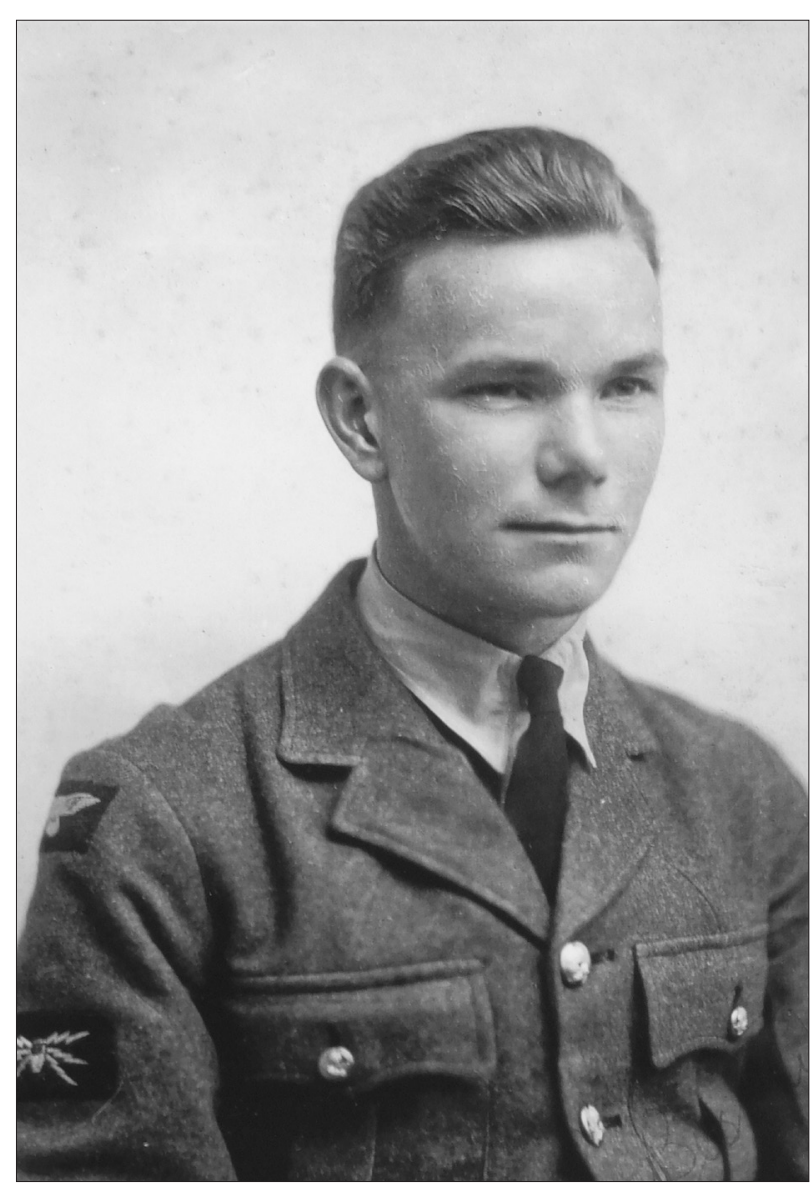

PLATE 1 - Aircraftsman W.R.J. Dingle, recently qualified Wireless Operator.

to 78 Squadron based at Linton-on-Ouse, near York, after spending two and a half months at 1652 Conversion Unit, Marston Moor, training on Halifax bombers.

Over the coming months they would take part in what would become known as the Battle of the Ruhr, be involved with the firebombing of Hamburg and take part in the opening phase of the Battle of Berlin. As was the normal 
operational procedure of the time, Bob flew his first three operations (ops) with other crews to gain experience.

Five ops later on 20 April 1943, Bob and his crew were posted to No 35 Squadron based at Graveley, Huntingdonshire. Although No 35 Squadron was a pathfinder squadron they flew with the main bomber force at first to gain further experience. But after Bob's twelfth op (to Bochum on 13/14 May) they flew as pathfinders marking the target in front of the main bomber force and guiding them to the target. They turned back twice (on 11 June when the target was Munster and on 27 August when the target was Nürnberg), when their navigational equipment, IFF (indicator friend or foe), GEE (navigational equipment) and $\mathrm{Y}$ equipment (target finder) instruments blew up or otherwise failed, returning to Graveley early after jettisoning their bombs, markers and flares in the North Sea. The raid on Krefeld (Bob's sixteenth op on 21/22 June) was particularly disastrous for No 35 Squadron. Six of nineteen Halifaxes from 35 Squadron were lost that night - two were lost at sea, three were shot down by night-fighters and one just managed to stagger back and ditched some 30 miles east of Cromer after being damaged by flack. That crew was all saved but of the other five crews 20 were killed and 16 made prisoner of war (Chorley 1996). Bob and his crew were lucky and came through undamaged.

In late July Bomber Command turned its attention on Hamburg and over an eleven-day period, bombed the city on four occasions while the American Eighth Air Force targeted the docks, U-boat construction yards and various factories during the day. Bob and crew took part in all four raids. British losses over those four nights were light with 12 aircraft out of 791 lost on the night of 24/25 July, 17 out of 787 aircraft lost on the 27/28 July, 28 out of 777 on 29/30 July and a further 28 out of 740 on the 2/3 August (Middlebrook \& Everitt 2000). These relatively light losses were attributed to the first use of windows or chaff - small strips of aluminium that are capable of producing false echoes on the enemy's radar. It was extremely hot and very dry on the second Hamburg raid and the bombing was highly concentrated. A massive firestorm raged for many hours killing an estimated 40000 civilians (Middlebrook \& Everitt 2000). Bob and crew were briefed for the Peenemünde raid (17/18 August) but for some reason, Bob could not remember why, they were stood down. August 1943 was a busy month and Bob and his crew took part in eight ops including two flying over the Alps to Turin so that by the end of that month they had completed their first tour of operations (30 ops). They immediately embarked on a second tour completing a further six ops over the coming three months that took them to the end of November 1943.

By mid-December 1943 Bob had flown 38 successful missions including six trips to Berlin. By then the crew was highly experienced, highly decorated (see appendix 1 for awards to Bob's crew) and five - including Bob - had been commissioned, though he was still flying as a Flight Sergeant. That month 35 Squadron was issued with new B Mark III Halifaxes and on 20 December four of these aircraft, including Bob's, were sent to attack Frankfurt.

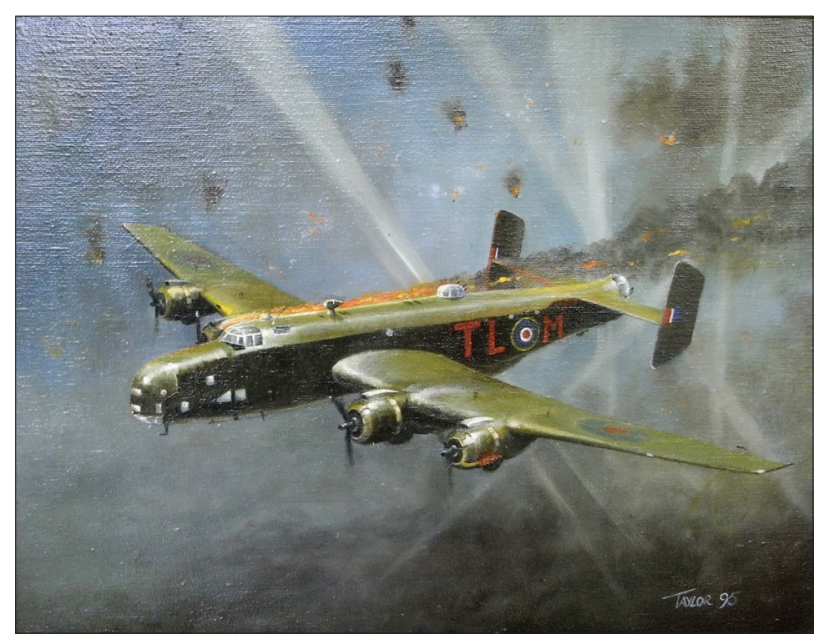

PLATE 2 - "Time to go. Good luck everybody!". Painting by I.G. Taylor, 1995.

Halifax HX270 (M) took off at 1730 hours. Unfortunately, soon after take-off their airborne, ground scanning radar system (H2S) failed, so that they were unable to drop their target markers. Despite this they continued on and bombed the target with high explosives and incendiaries. Up until then the flight had been uneventful and no damage had been experienced from either the ground defences (flack) or night-fighters. However, on their way back home and shortly after crossing the German/Belgian border at an altitude of about 20000 feet, one of the inner engines inexplicably caught fire. All attempts to extinguish the fire were unsuccessful, and when the fire spread to the main fabric of the aeroplane close to where the marker flares were stored, the pilot had no option but to give the order to bail-out (pl. 2).

Bob vividly recalled the barks and growls of countless dogs thousands of feet below as he floated down, disturbed by the sound of hundreds of aeroplane engines passing overhead. He landed alone in a ploughed field and after burying his parachute he began to walk in a SW direction until 0500 hours next morning. He spent the day hidden in a haystack near Wellen, Belgium, and at dusk he began walking again in a SW direction. About half an hour later he spoke to a farmer who took him home. Three hours later a man arrived with a bicycle who took him to a small town where he spent the night with a family whose name was never known to him. On the morning of 22 December he cycled to a farm where he met up with his flight engineer, Flight Sergeant William (Bill) Sinclair. Two members of this unnamed family then cycled with them to Neder Rechem some miles away, where they spent the night with the leader of the local underground. They had successfully linked up with the escape chain run by Walthère Dewé - a noted resistance leader during both world wars who was shot and killed some weeks later. Next day Bill and Bob caught a tram to Liège where they spent the next 13 days in hiding. On 5 January 1944 they were joined by Sgt H.L. Pike, an RAF Observer (navigator). The following day they were to be taken by train to Brussels but a random search of their train by the Gestapo revealed 
that although their identity cards passed scrutiny they did not have work permits. Taken prisoner, they were initially held in the civilian prison at Liège for six days in solitary confinement. Bob was sent to Stalag IVB (Mühlberg) where he spent the rest of the war as a POW.

Stalag IVB was liberated by the Russians on 23 April 1945 but it was several days before Bob and the rest of his fellow POWs were allowed to cross the River Elbe and make contact with other allied troops. Their return journey to the United Kingdom was in three stages - they marched/ walked most of the distance from Mühlberg to Halle; air transport from Halle to Brussels; then air transport from Brussels to an airfield near Harwell, Oxfordshire.

\section{BOB'S MISSIONS}

Bob took part in 41 operational sorties of which 38 were successful - safe return after bombing; plus two early returns due to instrument failure and his final op when his Halifax crashed in Belgium after bombing the target. Most were completed with his regular crew - James Henry Wright and Harold Matthews were his pilot and bomb aimer respectively on 38 occasions, Sydney Colin Rive Mackie was his navigator 37 times, Thomas Andrew Robson was Bob's rear gunner on 35 ops and Winston Barrington was his mid-upper gunner 31 times. Sidney Jackson, who was Bob's original flight engineer, suffered from chronic air sickness and was allowed to re-muster as an air traffic controller after completing 12 ops with Bob. He was replaced by S.J. Butler who flew nine ops with Bob and William Sinclair who completed 16 ops. All told, Bob flew operationally with a total of 30 Airmen. Of these 14 were killed in action, eight were made prisoners of war and seven were decorated. Four of Bob's regular crew were each awarded DFCs (see appendix 1). In addition, Kenneth James Rees, a mid-upper gunner who flew just once with Bob, received a DFM. James Bernard Anthony Scannell, who flew twice with Bob, was awarded both the DFM and DFC and Norman Francis Williams, an Australian who flew twice with Bob, was the most decorated non-commissioned officer in the Royal Australian Air Force in World War II, receiving the CGM (Conspicuous Gallantry Medal) whilst with 35 Squadron to go with the DFM and bar he had been awarded with 10 Squadron RAF.

\section{EARLY ANTARCTIC SERVICE}

Immediately post-war Bob served with a number of conversion units before joining 46 Squadron as a Flight Lieutenant flying Dakotas out of Stoney Cross. He was demobbed in late November 1946 and re-joined the GPO, taking an accountancy course at Bristol. In 1949 he came to Australia, securing a free berth on the MV Somersetshire. Sponsored by an aunt, who had settled in Griffith after the First World War, she had secured for him a job with the Murrumbidgee Irrigation Commission. On arrival Bob took one look at the set-up and left for Tasmania. He landed at Burnie where he was offered three jobs-as an insurance agent in Hobart, as a clerk with an aluminium mine on the Tamar River and, the one he accepted, as a clerk with the Mount Lyell Mining and Railway Company, Queenstown. The office work he undertook involved, amongst other duties, twice daily weather observations. Here he developed a lasting passion for the Tasmanian wild country and learned to tolerate the ever persistent rain and drizzle peculiar to the west coast of the Island State. All told he spent an enjoyable five months on the staff but this was not the life for him. A magazine article about Australia's sub-Antarctic islands-Heard Island and Macquarie Island - fired his interest so that when in March 1950 The Mercury, Tasmania's daily newspaper, carried an advertisement from the Commonwealth Bureau of Meteorology looking for trainee Weather Observers he applied with the express intention of going south.

He underwent a training course in Melbourne and was posted to RAAF Forest Hills near Wagga Wagga, New South Wales, to gain experience. January 1951 saw him on board HMAS Labuan on his way to Heard Island as part of the Australian National Antarctic Research Expeditions (ANARE) where he spent his first winter south. With hindsight, Heard Island was Bob's favourite Antarctic place - it had it all - the mixture of wildlife and vegetation, ice and snow, coastal and mountainous scenery. Whilst there Bob, Nils Lied and Ken Brown completed an epic 16-day trek, circumnavigating the island while doing a seal count (Law \& Béchervaise 1957). This was a self-supporting expedition, without radio contact - for which they had to carry all their personal equipment, food, cooking stove and utensils, fuel and camping gear. In 1951 the glaciers radiating out from Big Ben flowed down to the sea. Since then the glaciers have retreated inland as a result of global climate change, so that large pro-glacial lakes or lagoons have formed on the land between the glaciers' snouts and the sea. The 1951 trip would now be impossible on foot as well as being precluded under health and safety considerations.

Back in Australia at Port Hedland Bob volunteered and was accepted for a second Antarctic tour on Macquarie Island but he was asked to defer this appointment and be part of the team to establish Australia's first Continental Antarctic Base, to be called Mawson Station during the 1953-54 summer. In February 1954 Mawson Station was established on an isolated outcrop of rock in MacRobertson Land. Bob was the sole Weather Observer in the party of ten (pl. 3). The party was relieved just over a year later and in January 1956 the London Gazette announced that:

The Queen has been graciously pleased, on the advice of Her Majesty's Australian Ministers, to approve the following awards of the Polar Medal for good services to all members of the Australian National Antarctic

Research Expedition to Mawson, 1954-55.

The Station Leader, who already had a Polar Medal, received an additional clasp dated Antarctic 1954-55. Bob and seven others received the medal with clasp dated Antarctic 1954-55, and the French Observer who had spent the year with them received the medal and clasp but it was not gazetted. Thus Bob added a Polar Medal to the Distinguished Flying Medal, 1939-45 Star, Air 


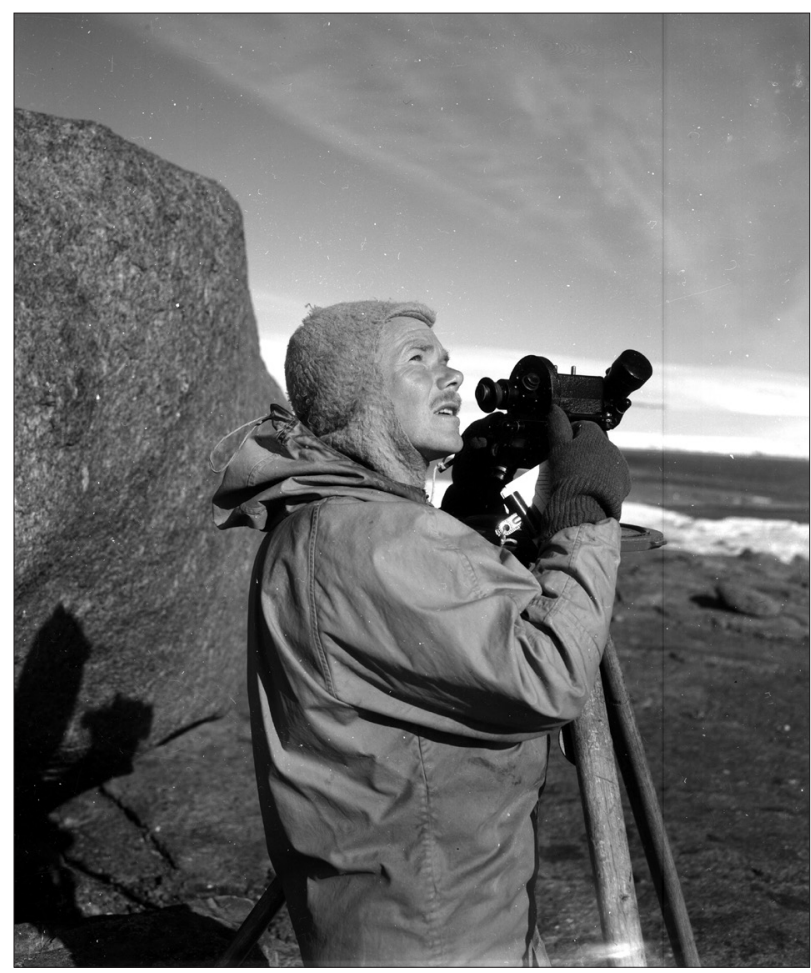

PLATE 3 - Bob Dingle using a theodolite near Mawson Station in February 1955. Photograph courtesy of the Australian Antarctic Division.

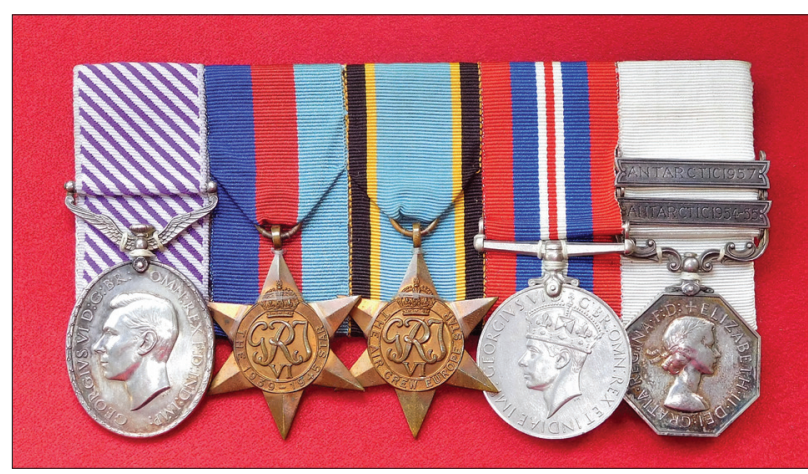

PLATE 4 - Bob Dingle's unique group of medals left to right: Distinguished Flying Medal (1380581. ACT. F. SGT. W.R.J. DINGLE. R.A.F.), 1939-45 Star, Air Crew Europe Star, War Medal, ERII silver Polar Medal with two clasps Antarctic 1954-55 and Antarctic 1957 (WILLIAM R.J. DINGLE).

Crew Europe Star and War Medal he had received during the Second World War (Poulsom \& Myres 2000) (pl. 4).

Bob spent the 1956 winter on Macquarie Island (pl. 5). Whilst there he was invited to be the Officer-in-Charge, and sole Meteorological Observer of Australia's second Antarctic Station to be established during the 1956-57 summer. The MV Kista Dan relieved Macquarie Island and, with Bob on board, arrived back in Melbourne on 11 December 1956. Six days later he was back on board the Kista Dan on his way to the Vestfold Hills, an icefree oasis in Princess Elizabeth Land, where they began building Davis Station. A six day turn-around between two wintering years was most unusual; a year or two gap between consecutive overwinterings was the norm. At other times

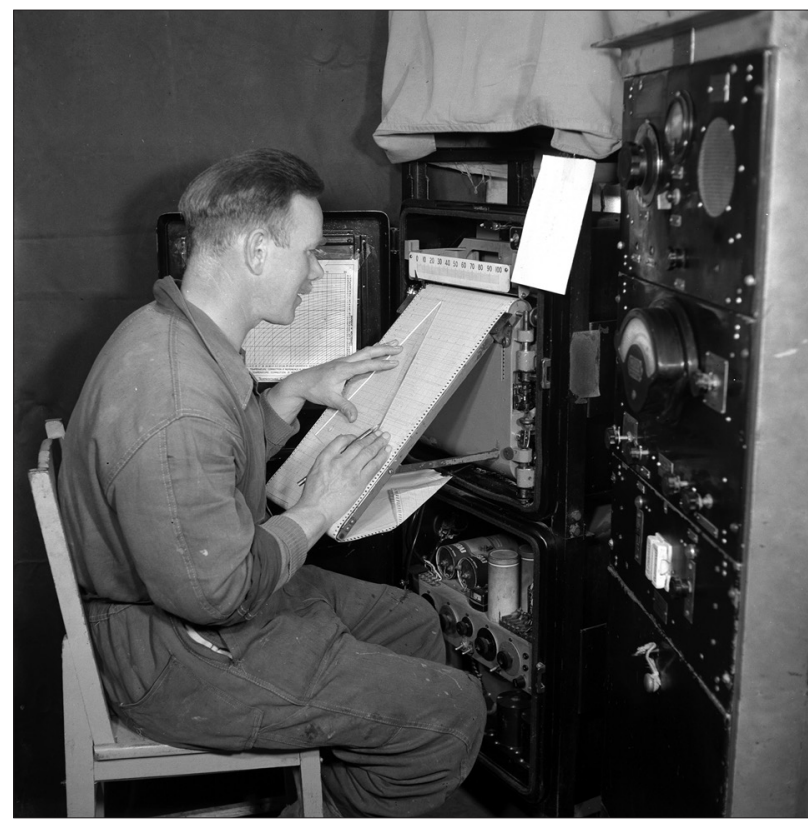

PLATE 5 - Bob Dingle working the radiosonde recorder at Macquarie Island in 1956. Photograph courtesy of the Australian Antarctic Division.

between trips south, Bob had been sent by the Bureau of Meteorology to various RAAF stations around Australia, and to the Giles Weather Station in Central Australia that had been established to satisfy launch activities at the Woomera rocket range. On one of these gap years early in the sequence Bob took time out to go to New Zealand and visit the families of his bomber crew who had been killed during the war.

Just five men made up the Davis 1957 wintering party (pl. 6). As well as improving their prefabricated living quarters they carried out research projects in meteorology and geology, maintained an all-sky camera for auroral studies, trained dogs and explored the local area. A very full program had been successfully carried out and in January 1960 the London Gazette carried the announcement that all five had been recognised with the award of the Polar Medal or as in Bob's case an additional clasp dated Antarctic 1957 as he was already the recipient of this medal.

\section{BOB'S ANTARCTIC MEDALLIONS}

Today Australian Service Medallions are awarded to all members of Australian Antarctic expeditions who have wintered at Macquarie Island, Heard Island or on one of the continental Antarctic bases. The medallions are usually presented at the changeover ceremony when the first ship of the season arrives at the station. Bob wintered five times on Australian bases (fig. 1) and one might assume he would have been awarded five medallions. Given to acknowledge special recognition now that the Imperial Polar Medal was no longer being awarded to all, the first medallions were issued in August 1971 to all who had wintered south of $60^{\circ} \mathrm{S}$ and at Heard Island for the years 1968, 1969 and 1970; Macquarie Island personnel were added to the list in 1973. 


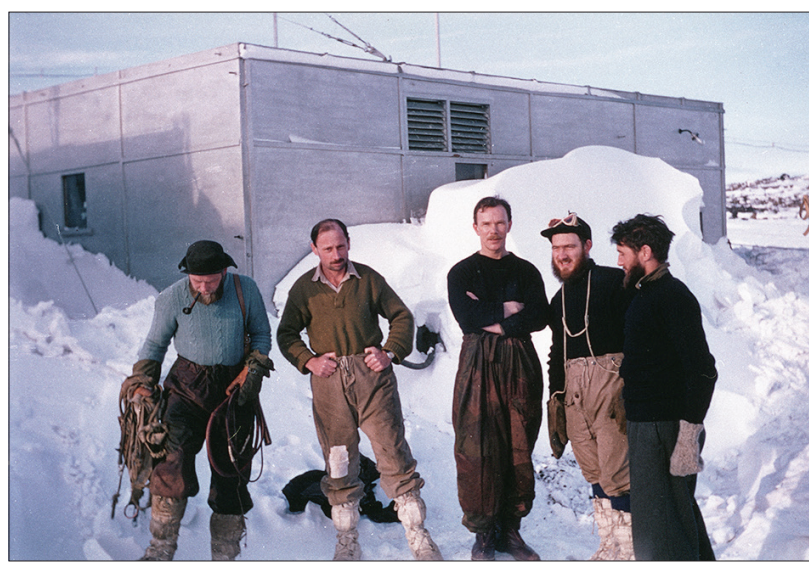

PLATE 6 - The 1957 Davis party left to right Nils Lied, Bruce Stinear, Bob Dingle, Alan Hawker and William Lucas. Photograph courtesy of the Australian Antarctic Division.

In 1997 it was decided to retrospectively acknowledge the service of those men from 1948 onwards who had wintered but had not been awarded a Polar Medal. Bob, who had received the Polar Medal for his time at Mawson and Davis, thus only received three service medallions (pl. 7).

\section{LATER ANTARCTIC SERVICE}

In August 1958 Bob was granted special leave from the Bureau whilst attached to ANARE, and was appointed Officer-in-Charge of Wilkes Station following its transfer from the United States Antarctic Research Program (USARP) to ANARE in February 1959. In addition to his Officer-inCharge duties Bob carried out a limited research program for the Meteorology Department at Melbourne University (UNIMET). This proved to be Bob's most difficult Antarctic posting. On 7 April 1959 one of the two diesel mechanics suffered a nervous breakdown and had to be confined and sedated. Three months after Henry Brandt went crazy the other mechanic, Hartley Robinson, was accidently crushed under the tracks of his tractor when it rolled down a slope. The loss of both diesel mechanics was a disaster but Antarctic expeditioners are invariably multi-skilled and highly adaptable and the Wilkes crew managed to keep the station up and running (Bowden 1997). Bob's father died on 31 December 1959 while he was at Wilkes.

In July 1961 Bob was again granted special leave from the Bureau of Meteorology whilst attached to UNIMET to join the USARP team at Byrd Station. Here he performed routine weather observations for the United States Weather Bureau (USWB) and carried out a series of snow drift observations for UNIMET during the 1962 winter.

Back in Australia he spent a year and a half at Willis Station (east of Cairns in the Coral Sea). Then, Willis station had a population of just three: two radio operators and one weather observer. In addition to his other duties Bob carried out routine weather observations for UNIMET. The fishing was good and the location was very desirable for amateur radio contacts with the rest of the world

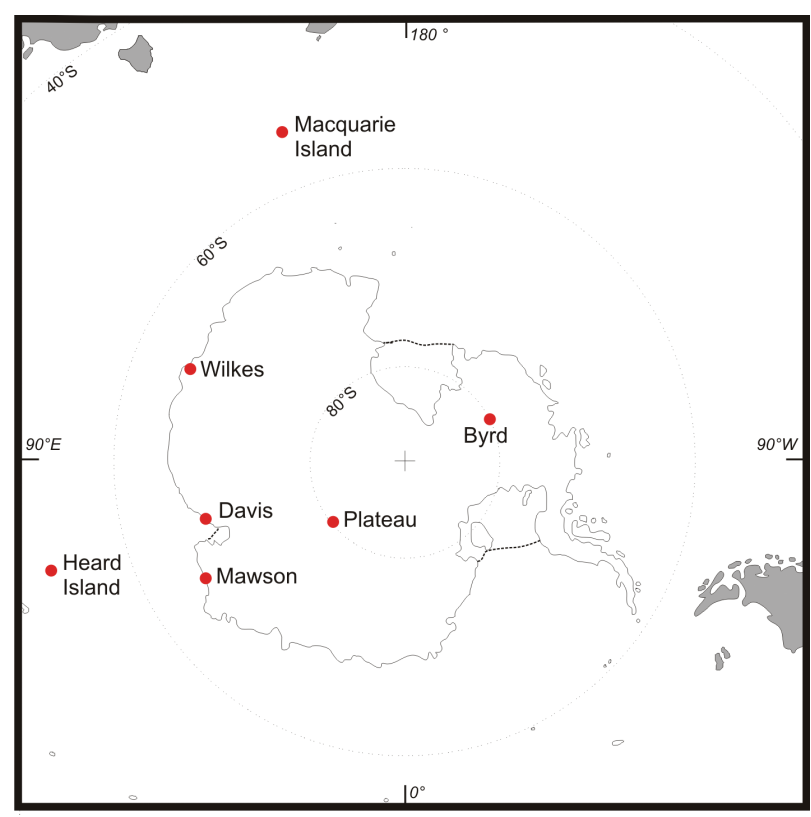

FIG. 1 - Where Bob wintered in the Antarctic.

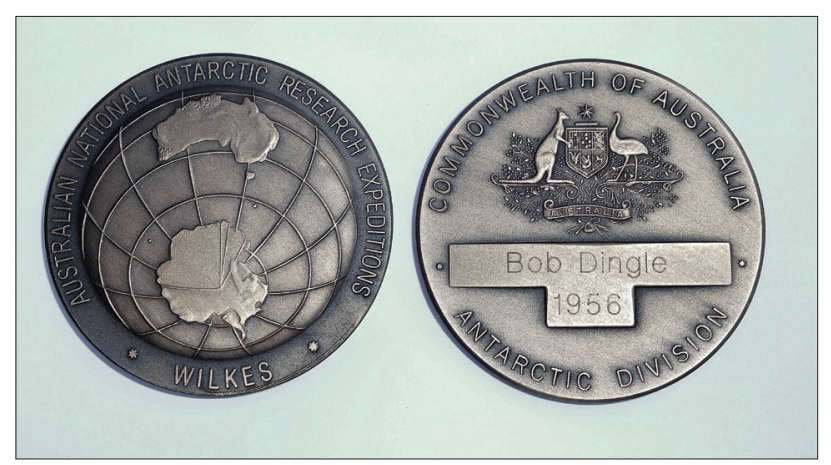

PLATE 7 - Bob Dingle's Antarctic Service Medallion for his 1956 winter at Wilkes.

but his companions were quarrelsome. On his return he spent a very enjoyable six weeks on the summit of Mount Buller, just $200 \mathrm{~km}$ east of Melbourne, testing equipment for the CSIRO.

In December 1966 Bob was again seconded to the USARP and spent the 1967 winter at Plateau Station where he carried out routine weather observations for the USWB and carried on research for UNIMET. Plateau Station, at an elevation of 11980 feet $(3624 \mathrm{~m})$ is located at $79^{\circ} 31^{\prime} \mathrm{S}$, $40^{\circ} \mathrm{E}$ and is one of the most isolated and coldest places on earth. Summer temperatures (November to March) average $-40^{\circ} \mathrm{C}\left(-40^{\circ} \mathrm{F}\right)$ and winter temperatures (April to October) average $-70^{\circ} \mathrm{C}\left(-96^{\circ} \mathrm{F}\right)$ with an all-time low of $-86.1^{\circ} \mathrm{C}\left(-123^{\circ} \mathrm{F}\right)$ recorded in June 1968 , a few months after Bob had gone home. The base was only manned for three years with a team of four US Navy personnel to support four civilian researchers.

As a result of a cooperative program between the Australian and the US weather services Bob then spent the next four years, from August 1968 until March 1972, as the senior Australian weather observer on board the US 
Navy Ship Eltanin. The cruises were almost exclusively in the Southern Ocean between South America and 70 East of Greenwich. Bob served on 18 of these cruises (numbers 35 to 52) doing oceanographic research across a wide range of marine science disciplines. Bob's mother, who had migrated to Victoria, Australia, after the death of her husband in 1959, died on 18 September 1969 in St Kilda.

\section{BOB'S MISSING MEDAL}

Bob's service with USARP at Byrd and Plateau stations would have made him eligible for the United States Antarctic Service Medal (US ASM) with "WINTERED OVER" clasp. He is featured in several US files concerning the initial distribution of the medal to US and foreign civilians, including being numbered Number 137 in a letter dated 25 May 1965 from the Office of the Assistant Secretary of Defence for International Security Affairs leading Colonel Albert F Gleim (Colonel USA Retired), in a personal communication, to conclude: "it seems virtually certain he was awarded and issued the medal ... but there is nothing to absolutely to confirm this (such as a report of a presentation ceremony or a receipt)". Then Bob ought to have been awarded the Antarctic Service Medal with bronze "WINTERED OVER" in accordance with the Assistant Secretary's letter and sent a gold (coloured) clasp to replace the bronze one after completing his second year at Plateau station. Bob never received his medal and I can only conclude that for some unexplained reason they were never issued or were lost in the post.

\section{RETIREMENT}

Bob served as weather observer on Norfolk Island until April 1973 and then spent the next two and a half years attached to the Special Services Section of the Tasmanian Regional Bureau in Hobart. He resigned from the Australian Meteorological Service in December 1975, aged 55 and retired to Swansea, thus beginning a long and happy retirement. Periodically he would take off on bushwalking trips around Tasmania (pl. 8), and while at home he enjoyed listening to his extensive collection of classical symphony and choral music on tape. He was an accomplished photographer and held a number of slide shows for local volunteer groups including the fire brigade and SES. Indeed a book of his Antarctic photographs was published a few years ago (Dingle 2011). He was interviewed in 2011 by Ingrid Mcgaughey as part of the ANARE Club's Oral History Project; copies of the record of interview have been lodged with the Australian Antarctic Division, the Tasmanian Museum and Art Gallery and the ANARE Club.

In addition to these indoor and outdoor solitary activities, Bob kept in touch with his ANARE colleagues and Met Bureau workmates. He was a regular attendee at ANARE Midwinter Dinners, and a good correspondent with those further away. In 2012 he sold up and moved into the May

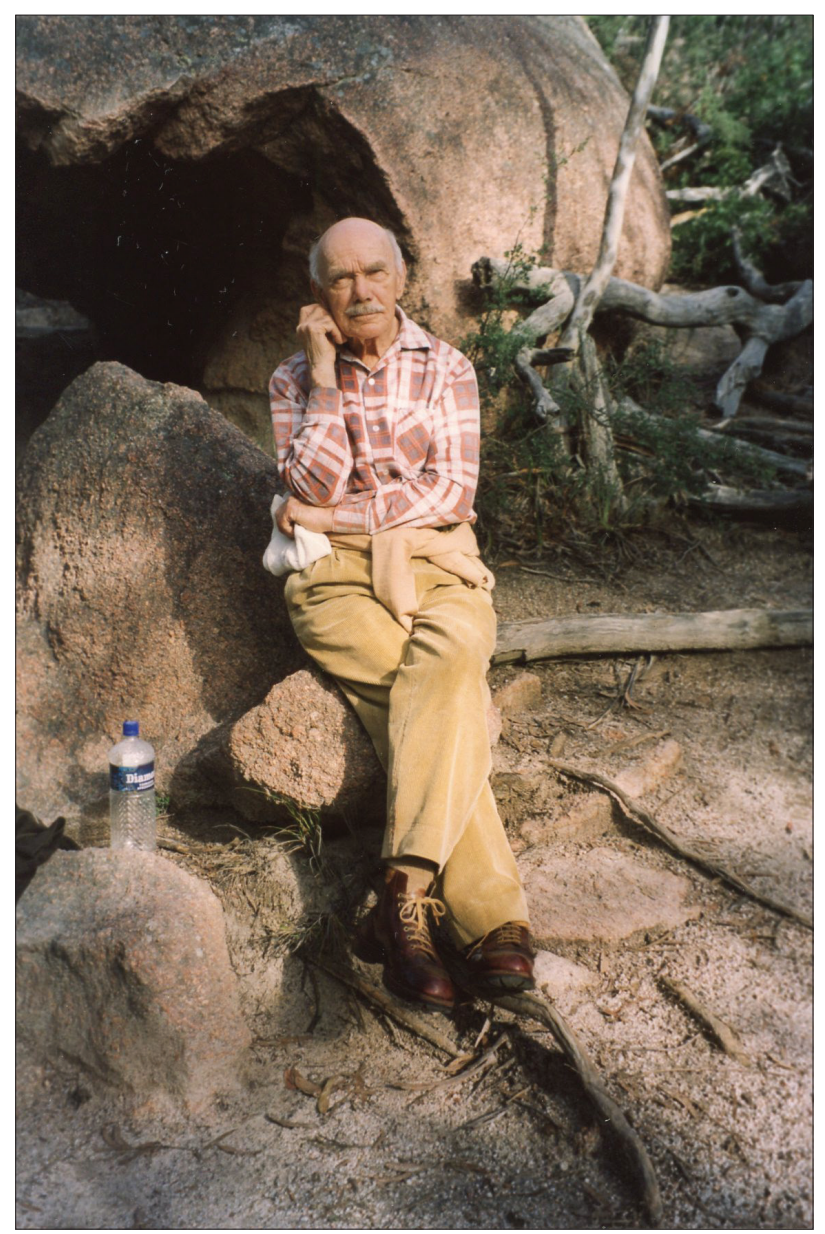

PLATE 8 - Bushwalking in Tasmania, early 1990s.

Shaw Nursing home in Swansea on 4 June. William Robert John Dingle died after a long and extraordinary life on 5 September 2016, aged 95.

\section{ACKNOWLEDGEMENTS}

My thanks to the Dingle family, especially Mrs Janet Ivey for details of Bob's early life, and to Bob's Swansea neighbour Mrs Margo Spurr for information on Bob's period of retirement. I also thank my daughters Dr Jennifer Selkirk-Bell and Ms Katherine Selkirk for mapping and editorial skills, and my wife Dr Patricia Selkirk for her support and enthusiasm for this writing project.

\section{REFERENCES}

Bowden, T. 1997: The Silence Calling: Australians in Antarctica 1947-97. Allen and Unwin, St Leonards, Australia: 593 pp.

Chorley, W.R. 1996: Royal Air Force Bomber Command Losses of the Second World War 1943. Midland Publishing, Manchester, UK: $494 \mathrm{pp}$.

Dingle, W.R.J. 2011: Antarctica: photographs by Bob Dingle. Picture editor Susan Gordon-Brown. Blurb.com, Melbourne, Australia: 80 pp. 
Law, P. \& Béchervaise, J. 1957: ANARE Australia's Antarctic Outposts. Oxford University Press, Melbourne, Australia: $152 \mathrm{pp}$.

Middlebrook, M. \& Everitt, C. 2000: The Bomber Command War Diaries: An Operational reference book 1939-1945. Midland Publishing, Hinckley, UK: 808 pp.

Poulsom, N.W. \& Myres, J.A.L. 2000: British Polar Exploration and Research: A historical and medallic record with biographies 1818-1999. Savannah Publications, London, UK: 729 pp.

Stoneley, J. 1980: Jenny's War. Hamlyn Paperbacks, Feltham, UK: 344 pp.
Vercoe, T. 2006: Survival at Stalag IVB: soldiers and airmen remember Germany's largest POW camp of World War II. McFarland \& Company, Jefferson, USA: 202 pp.

WW2 RAF Evasion and capture files (WO 208 series) 3337/590 for Matthews, 3338/765 for Dingle and 3339/1398 for Sinclair. Public Records Office, Kew, UK.

(accepted 6 November 2018)

\section{Appendix 1 - The fate of the crew of HX270 (M)}

Bob was the last to leave the stricken aircraft. He followed the bomb-aimer and navigator through the escape hatch forward of the front turret while the engineer and mid-upper gunner exited through the entrance hatch. The rear-gunner Pilot Officer Thomas A. Robson, who vowed he would never jump, stayed on board and died along with the pilot Flight Lieutenant James H. Wright when the plane crashed. The navigator Flight Lieutenant Sidney C.R. Mackie also died when his parachute failed to open. Three fatalities, all New Zealanders, all decorated with the Distinguished Flying Cross. Their remains were subsequently reburied together in Heverlee War Cemetery (Chorley 1996).

Of the three other members of Bob's crew, Flight Sergeant William MacRae Sinclair (Flight Engineer) was captured with Bob at Liège. The mid-upper gunner Sergeant Winston Barrington was captured on 6 January 1944 and interned with Bob in Stalag IVB. His widowed mother Florence had remarried a German in 1933 and lived in Austria during the Second World War. On learning of Winston's incarceration in Mühlberg she moved there and got herself smuggled into the camp and with her breasts taped down succeeded in passing herself off as a man until the camp was liberated (Stoneley 1980, Vercoe 2006). Florence's story, with a degree of poetic licence was been made into a 1985 TV series with the title "Jenny's War", and a 1992 film of the same name starring Dyan Cannon in the lead role and Hugh Grant playing the part of Winston. Pilot Officer Harold Matthews DFC, bomb aimer, evaded capture for four and a half months until captured at Dinant on 10 May 1944. He was incarcerated in Camp L7 (WW2 RAF Evasion and capture files, Public Records Office).
Decorations awarded to members of Bob Dingle's crew (pl. A1)

Distinguished Flying Cross London Gazette 8 October 1943, page 4449

Acting Flight Lieutenant James Henry WRIGHT (NZ 414717) RNZAF No 35 Squadron

Pilot Officer Sidney Colin Rive MACKIE (NZ413713) RNZAF No 35 Squadron.

Pilot Officer Harold MATTHEWS (149150) RAFVR No 35 Squadron

One night in September 1943 Flight Lieutenant Wright and Pilot Officers Mackie and Matthews were pilot, navigator and air bomber respectively of an aircraft detailed to attack Mannheim. The operation demanded a high degree of skill and the success achieved reflects great credit on the efforts of these members of aircraft crew who executed their task faultlessly. They have taken part in many previous operations and have always displayed courage, determination and devotion to duty of a high order.

Distinguished Flying Medal London Gazette 16 November 1943, page 5026

Acting Flight Sergeant William Robert John DINGLE (1380581) RAFVR No 35 Squadron

Distinguished Flying Cross London Gazette 10 December 1943, page 5381

Pilot Officer Thomas Andrew ROBSON (NZ 414893) RNZAF No 35 Squadron.
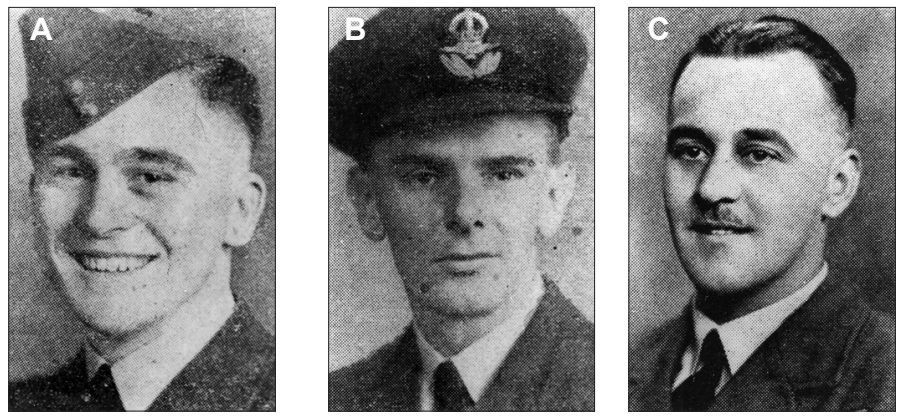

PLATE A1 - Members of Bob Dingle's crew. (A) Flight Lieutenant J.H. Wright, (B) Flight Lieutenant S.C.R. Mackie and (C) Pilot Officer T.A. Robson (photo credit The Weekly News, the Airforce Museum of New Zealand). 
